\title{
COMPARISON OF THE QUALITY OF CAGE AND ORGANIC EGGS AVAILABLE IN RETAIL AND THEIR CONTENT OF SELECTED MACRO-ELEMENTS
}

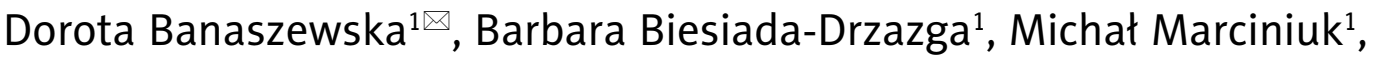 \\ Cyril Hrnčár², Henrieta Arpášová3 ${ }^{3}$ Sabina Kaim-Mirowski ${ }^{1}$ \\ ${ }^{1}$ Institute of Animal Sciences and Fisheries, Siedlce University of Natural Sciences and Humanities \\ Prusa 14, 08-110 Siedlce, Poland \\ ${ }^{2}$ Department of Small Animal Science, Slovak University of Agriculture in Nitra \\ Trieda A. Hlinku 2, 94976 Nitra, Slovakia \\ ${ }^{3}$ Department of Poultry Science and Small Farm Animals, Slovak University of Agriculture in Nitra \\ Trieda A. Hlinku 2, 94976 Nitra, Slovakia
}

\begin{abstract}
Background. The chicken egg is a food product with a rich content of nutrients, such as proteins, vitamins, lipids, and minerals with high bioavailability. Furthermore, eggs are easy to prepare and a relatively inexpensive component of the human diet. The aim of this study was to compare the quality of eggs from an organic and a conventional farm and their content of $\mathrm{Na}$ and $\mathrm{K}$.

Material and methods. The research material consisted of eggs from laying hens reared in two different systems - organic (according to standards for organic farming and with access to a chicken run) and cage. Forty eggs from each group were analysed. Egg quality traits were divided into destructive and non-destructive. In addition, potassium $(\mathrm{K})$ and sodium $(\mathrm{Na})$ contents were determined in the whole egg, yolk and albumen. Results. The research results indicated slightly better quality of eggs from organic farming compared to eggs from cages in the case of most physical properties. The data clearly show that the content of sodium and potassium in the albumen, yolk and whole egg was higher in the eggs of chickens raised organically compared to the eggs of chickens reared in cages $(P \leq 0.05)$.

Conclusions. The research results indicate a slightly better quality of eggs from the organic farm compared to eggs from cages in the case of most physical properties, as well as the content of macro-elements. Eggs in both systems are produced following scientific management practices. There are many myths among consumers regarding the nutritional quality of eggs produced in different systems. This information can be useful for raising awareness among consumers selecting eggs.
\end{abstract}

Keywords: egg quality, macro-elements, rearing system

This work was supported by internal University funds. 


\section{INTRODUCTION}

The chicken egg is a food product with a rich content of nutrients, such as proteins, vitamins, lipids, and minerals (Abd El-Hack et al., 2018; Seuss-Baum, 2007), with high bioavailability (Kijowski et al., 2013; Wellman-Labadie et al., 2007). In recent years, diverse opinions have been disseminated about the effect of eggs in the diet on human health, and in particular about the recommended quantity of eggs in the diet (Kijowski et al., 2013; McNamara, 2010; Wężyk and Gilewski, 2018). This mainly had to do with concern about the adverse effects of the cholesterol, fat and calories in egg yolks on human health. Currently, eggs are no longer treated as foods that should be restricted in the daily diet, and are even regarded as functional foods (Biesiada-Drzazga et al., 2020). For humans, eggs are both food and a source of life-giving substances (Kijowski et al., 2013). Furthermore, eggs are easy to prepare and a relatively inexpensive component of the human diet. Eggs for food are obtained mainly from domestic fowl. Mass egg consumption around the world is primarily based on chicken eggs (Anders, 2004a; 2004b). According to Commission Directive 2002/4/EC of 30 January 2002 , four systems for keeping laying hens can be distinguished: cage, barn, free range and organic (Dyrektywa..., 2002). In addition, since January 1, 2012, the conventional battery-cage system has been prohibited, and cages must be 'enriched', with space for a nest, litter, and a perch, with a cage area of not less than 750 $\mathrm{cm}^{2}$ per bird (Bełkot and Gondek, 2014). The structure of the rearing system of laying hens in the European Union is very diverse. In most EU countries the cage system is dominant (Portugal, Spain, Czech Republic, Greece, Slovakia, Lithuania, Latvia, and Estonia). In Germany, the Netherlands, Sweden and Luxembourg, the majority of laying hens are reared in the barn system, whereas in Great Britain and Ireland the free range system is preferred, and in Denmark nearly $30 \%$ of laying hens are reared in an organic system (https:// kipdip.org.pl/pl/news/struktura-chowu-kur-niosek-wunii-europejskiej-w-2017-roku). In Poland, consumers are primarily supplied with eggs from the cage system. However, recent years have seen an increase in the consumption of eggs from free range or organic rearing systems. The organic system of housing laying hens may have a positive effect on the egg contents, in line with consumer expectations (Krawczyk et al., 2011). Making a chicken run available to layers also affects the physical characteristics of the eggs, such as their weight and shell strength (Krawczyk and Gornowicz, 2010). The fundamental requirement in the production of organic eggs is to provide layers with green runs and feed them organic feed. However, organic chicken farming is very costly, which increases the price of eggs. The physiological properties of eggs play an important role in determining consumer preferences. Smell, taste and sensory memory are important to all consumers. When purchasing food, people pay attention to the freshness, quality and price of the product. There is also an increasing focus among the public on health (Babicz-Zielińska, 2001; Wielewska, 2004), associated with nutrition. The inclusion of eggs with health-promoting properties in the daily diet is highly beneficial (Sim, 2006; Surai and Sparks, 2001; Trziszka, 2009; Trziszka et al., 2013), and egg consumption can reduce the risk of a number of diseases (Nys et al., 2011), because the substances contained in them improve body condition and supplement the human diet with nutrients that may be lacking (Seuss-Baum, 2007). In addition, eggs are considered nutraceuticals, i.e. natural food with health-promoting and therapeutic functions (Nain et al., 2012), and 'designer eggs' may contain several times more biologically active substances (Trziszka et al., 2013; Walczak et al., 2016). An undoubted advantage of eggs is that their composition can be modulated relatively easily, in the case of both nutrients and elements (Szymanek et al., 2019). Specific diets for laying hens enable the production of eggs available on the market under many trade names, such as multi-grain eggs, eggs with marigold and red pepper extracts, herbal eggs, or eggs enriched with macro-elements. In addition, the myth of the high cholesterol content of eggs and its health implications has been refuted in recent years. Studies show that egg consumption has no negative effect on serum cholesterol levels (Hu et al., 2001). It is even recommended to eat several eggs a week (McNamara, 2010). Hence, it is worth focusing once again on comparison of eggs, especially those widely available in retail, their quality, and their content of selected macro-elements.

The aim of the study was to compare the quality of eggs from an organic and a conventional farm and their content of $\mathrm{Na}$ and $\mathrm{K}$. 


\section{MATERIAL AND METHODS}

The research material consisted of eggs from laying hens reared in two different systems - organic (according to standards for organic farming and with access to a chicken run) and cage (Kajdan-Zasnarska, 2013). The study was conducted in April 2018. Both groups of eggs were purchased at a supermarket belonging to one of the local retail chains in the Masovian Voivodeship in Poland. The eggs were from a conventional farm and an organic farm from the same voivodeship. Both cage and organic eggs were size M (Rozporządzenie..., 2008). The eggs selected for purchase had a use-by date within 14 days. Forty eggs from each group were analysed, for a total of 80 eggs. Eggs were assessed on the day of purchase and the next day. Prior to the analysis, they were stored under refrigerated conditions (about $4-5^{\circ} \mathrm{C}$ ).

Egg quality parameters were divided into those which required the shell to be broken and those that did not (non-destructive). The egg weight (g) was recorded using an electronic scale (RADWAG WPS 360 $\mathrm{C}$ scales, Radom, Poland) to within $0.1 \mathrm{~g}$. The depth of the air cell was measured using an Ovolux candling lamp and a millimetre scale.

The following characteristics of individual egg components were assessed:

1. Shell:

- colour - using a colour scale from 0 to 100

- weight - using an electronic scale to within $0.01 \mathrm{~g}$

- thickness - using a micrometer, in three places: the blunt end, pointed end, and mid-height (equator).

2. Albumen:

- thick albumen weight - using an electronic scale to within $0.01 \mathrm{~g}$

- thin albumen weight - using an electronic scale to within $0.01 \mathrm{~g}$

- thick albumen height - after breaking the egg and emptying its contents onto a glass plate, the height of the thick albumen was measured with a micrometer on a tripod at a distance of about $1 \mathrm{~cm}$ from the yolk

- length and width of thick and thin albumen using an electronic calliper
- concentration of hydrogen ions $(\mathrm{pH})$ - with a CP-251 pH meter to within 0.01 .

Based on the albumen height and weight of the egg, Haugh units were calculated according to the formula given by Williams (1992).

3. Yolk:

- weight - with an Ohaus electronic scale to within $0.01 \mathrm{~g}$

- diameter - with an electronic calliper

- colour - according to Roche's 15-point scale

- concentration of hydrogen ions $(\mathrm{pH})$ - with a CP-251 pH meter to within 0.01 .

The data were used to calculate the yolk index and the percentage share of each morphological component of the egg in the weight of the whole egg.

In addition, the potassium $(\mathrm{K})$ and sodium $(\mathrm{Na})$ content of the egg yolk and albumen were determined separately. The content of $\mathrm{K}$ and $\mathrm{Na}$ in a homogeneous mixture was also calculated based on the percentage of yolk and albumen in the egg. The sodium and potassium content were determined by inductively coupled plasma optical emission spectrometry (ICPOES) on an Optima 8300 spectrometer (Perkin Elmer, Waltham, Massachusetts, USA). The determinations were made at wavelengths of $589.592 \mathrm{~nm}$ for sodium and $766.491 \mathrm{~nm}$ for potassium.

The instrument was operated under the following conditions:

- nebulizer spray chamber - Meinhard/Cyclonic

- injector - Quartz $2.0 \mathrm{~mm} \mathrm{ID}$

- resolution - normal

- read time $-20 \mathrm{~s}(\min )-50 \mathrm{~s}(\max )$

- resolution - normal

- plasma gas $-15 \mathrm{~L} / \mathrm{min}$, auxiliary gas $-0.2 \mathrm{~L} / \mathrm{min}$, nebulizer gas $-0.6 \mathrm{~L} / \mathrm{min}$, power $-1400 \mathrm{~W}$

- plasma view - radial.

The influence of the rearing system on the content of elements was assessed by one-way analysis of variance using the following mathematical model:

$$
Y_{\mathrm{ij}}=\mu+a_{i}+e_{\mathrm{ij}}
$$

where:

$Y_{\mathrm{ij}}$ - value of trait,

$\mu-$ mean for population,

$a_{i}-$ effect of i-th level of factor (rearing system),

$e_{\mathrm{ij}}$ - sampling error. 
Data were analysed by ANOVA using STATISTICA PL (2011) 10.0 software (STATISTICA version 10.0, StatSoft Inc., PL). The mean values and the SD of measured traits were calculated, and the significance of differences between groups was verified by Tukey's test at $P \leq 0.05$.

\section{RESULTS}

The data on selected morphological features of eggs from laying hens reared in an organic system and a cage system are presented in Table 1. Organic eggs weighed nearly $5 \mathrm{~g}$ less $(P \leq 0.05)$ than eggs from the cage system. The shape of eggs from the two rearing systems was very similar. It is worth noting that despite the smaller weight of eggs from the organic farm, the share of yolk was over 4 percentage points higher, while that of albumen was lower than in eggs from the

Table 1. Selected physical characteristics of eggs depending on the rearing system

\begin{tabular}{lcc}
\hline & \multicolumn{2}{c}{ Chicken rearing system } \\
\cline { 2 - 3 } \multicolumn{1}{c}{ Feature } & $\begin{array}{c}\text { organic } \\
n=40\end{array}$ & $\begin{array}{c}\text { cage } \\
n=40\end{array}$ \\
\cline { 2 - 3 } & mean \pm SD & mean \pm SD \\
\hline Egg weight, g & $60.36^{\mathrm{a}} \pm 3.43$ & $65.25^{\mathrm{b}} \pm 2.13$ \\
Egg length, mm & $56.48^{\mathrm{a}} \pm 1.74$ & $57.74^{\mathrm{b}} \pm 1.48$ \\
Egg width, mm & $43.91^{\mathrm{a}} \pm 1.01$ & $45.22^{\mathrm{b}} \pm 0.87$ \\
Egg shape index* & $1.28^{\mathrm{a}} \pm 0.03$ & $1.27^{\mathrm{a}} \pm 0.03$ \\
Shell weight, g & $6.36^{\mathrm{a}} \pm 0.33$ & $8.15^{\mathrm{b}} \pm 0.38$ \\
Total albumen weight, g & $33.81^{\mathrm{a}} \pm 3.83$ & $38.10^{\mathrm{b}} \pm 3.38$ \\
Yolk weight, g & $20.19^{\mathrm{a}} \pm 2.53$ & $19.00^{\mathrm{b}} \pm 1.43$ \\
Depth of air cell, mm & $6.45^{\mathrm{a}} \pm 0.75$ & $4.95^{\mathrm{b}} \pm 0.82$ \\
& Percentage of egg weight & \\
Shell & $10.54^{\mathrm{a}} \pm 0.66$ & $12.49^{\mathrm{a}} \pm 0.61$ \\
Albumen & $56.01^{\mathrm{a}} \pm 6.53$ & $58.39^{\mathrm{b}} \pm 5.62$ \\
Yolk & $33.45^{\mathrm{a}} \pm 4.72$ & $29.12^{\mathrm{b}} \pm 2.31$ \\
\hline
\end{tabular}

Means in rows with superscripts $(\mathrm{a}, \mathrm{b})$ differ significantly at $P \leq 0.05$.

*Egg shape index - ratio of long axis to short axis. cage system $(P \leq 0.05)$. The depth of the air cell was also statistically $(P \leq 0.05)$ greater in the organic eggs, which in this case may indicate a slightly longer storage period and thus less fresh eggs.

The shells of eggs from the organic system were much lighter in colour than those of cage eggs $(P \leq$ $0.05)$. The thickness of the shell of eggs from both systems differed only at the blunt end of the egg (Table 2). The shell of eggs from caged hens was $0.03 \mathrm{~mm}$ thinner at the pointed end than that of eggs from hens raised on the organic farm $(P \leq 0.05)$.

Table 2. Selected characteristics of the egg shell depending on the chicken rearing system

\begin{tabular}{lcc}
\hline & \multicolumn{2}{c}{ Chicken rearing system } \\
\cline { 2 - 3 } \multicolumn{1}{c}{ Feature } & $\begin{array}{c}\text { organic } \\
n=40\end{array}$ & $\begin{array}{c}\text { cage } \\
n=40\end{array}$ \\
\cline { 2 - 3 } & mean $\pm \mathrm{SD}$ & mean $\pm \mathrm{SD}$ \\
\hline Shell weight, g & $6.36^{\mathrm{a}} \pm 0.33$ & $8.15^{\mathrm{b}} \pm 0.38$ \\
Shell colour, points & $44.50^{\mathrm{a}} \pm 6.86$ & $80.00^{\mathrm{b}} \pm 5.61$ \\
Shell thickness at blunt end, mm & $0.36^{\mathrm{a}} \pm 0.02$ & $0.36^{\mathrm{a}} \pm 0.02$ \\
Shell thickness at equator, mm & $0.36^{\mathrm{a}} \pm 0.02$ & $0.37^{\mathrm{a}} \pm 0.03$ \\
Shell thickness at pointed end, $\mathrm{mm}$ & $0.40^{\mathrm{a}} \pm 0.03$ & $0.37^{\mathrm{b}} \pm 0.01$ \\
\hline
\end{tabular}

Means in rows with superscripts $(\mathrm{a}, \mathrm{b})$ differ significantly at $P \leq 0.05$

Table 3 presents data on albumen traits depending on the housing system. The albumen of eggs from caged hens had a higher total weight, and thus the weight of the thin and thick albumen was also greater than in organic eggs $(P \leq 0.05)$. Despite the greater weight of the albumen of eggs from the cage system, the height of the thick albumen in these eggs was smaller $(P \leq 0.05)$. The number of Haugh units, which indicate the quality and freshness of eggs, was also lower $(P \leq 0.05)$.

Table 4 shows that the organic eggs had a larger yolk diameter and height, which resulted in a larger yolk index compared to cage eggs $(P \leq 0.05)$. Yolk colour can range from pale yellow to dark orange. In the present study, the yolks of cage eggs were lighter in colour than organic egg yolks. 
Table 3. Characteristics of albumen depending on the chicken rearing system

\begin{tabular}{lcc}
\hline & \multicolumn{2}{c}{ Chicken rearing system } \\
\cline { 2 - 3 } \multicolumn{1}{c}{ Feature } & $\begin{array}{c}\text { organic } \\
n=40\end{array}$ & $\begin{array}{c}\text { cage } \\
n=40\end{array}$ \\
\cline { 2 - 3 } & mean \pm SD & mean \pm SD \\
\hline Total albumen weight, g & $33.81^{\mathrm{a}} \pm 3.83$ & $38.10^{\mathrm{b}} \pm 3.38$ \\
Thin albumen weight, g & $10.71^{\mathrm{a}} \pm 2.15$ & $12.14^{\mathrm{a}} \pm 1.54$ \\
Thick albumen weight, $\mathrm{g}$ & $23.10^{\mathrm{a}} \pm 2.62$ & $25.96^{\mathrm{b}} \pm 2.74$ \\
Thick albumen width, $\mathrm{mm}$ & $86.04^{\mathrm{a}} \pm 6.88$ & $86.20^{\mathrm{a}} \pm 7.69$ \\
Thin albumen width, $\mathrm{mm}$ & $117.96^{\mathrm{a}} \pm 2.40$ & $93.06^{\mathrm{b}} \pm 10.04$ \\
Thin albumen length, $\mathrm{mm}$ & $138.54^{\mathrm{a}} \pm 19.62$ & $136.15^{\mathrm{a}} \pm 12.98$ \\
Thick albumen length, $\mathrm{mm}$ & $100.63^{\mathrm{a}} \pm 8.52$ & $107.32^{\mathrm{b}} \pm 6.99$ \\
Albumen pH & $7.91^{\mathrm{a}} \pm 0.59$ & $8.93^{\mathrm{a}} \pm 20.73$ \\
Albumen height, mm & $3.70^{\mathrm{a}} \pm 0.57$ & $3.25^{\mathrm{b}} \pm 0.63$ \\
Haugh units & $54.53^{\mathrm{a}} \pm 6.92$ & $44.77^{\mathrm{b}} \pm 10.09$ \\
\hline
\end{tabular}

Means in rows with superscripts $(a, b)$ differ significantly at $P \leq 0.05$.

Table 4. Characteristics of the yolk depending on the chicken rearing system

\begin{tabular}{lcc}
\hline & \multicolumn{2}{c}{ Chicken rearing system } \\
\cline { 2 - 3 } \multicolumn{1}{c}{ Feature } & $\begin{array}{c}\text { organic } \\
n=40\end{array}$ & $\begin{array}{c}\text { cage } \\
n=40\end{array}$ \\
\cline { 2 - 3 } & mean $\pm \mathrm{SD}$ & mean $\pm \mathrm{SD}$ \\
\hline Yolk weight, g & $20.19^{\mathrm{a}} \pm 2.53$ & $19.00^{\mathrm{b}} \pm 1.43$ \\
Yolk diameter, mm & $43.21^{\mathrm{a}} \pm 2.02$ & $42.25^{\mathrm{b}} \pm 0.88$ \\
Yolk height, mm & $11.85^{\mathrm{a}} \pm 1.59$ & $8.45^{\mathrm{b}} \pm 1.05$ \\
Yolk index & $0.27^{\mathrm{a}} \pm 0.04$ & $0.20^{\mathrm{b}} \pm 0.03$ \\
Yolk pH & $6.63^{\mathrm{a}} \pm 0.82$ & $6.58^{\mathrm{a}} \pm 0.36$ \\
Yolk colour, points & $11.45^{\mathrm{a}} \pm 1.27$ & $8.30^{\mathrm{b}} \pm 1.30$ \\
\hline
\end{tabular}

Means in rows with superscripts $(\mathrm{a}, \mathrm{b})$ differ significantly at $P \leq 0.05$.
The data clearly show that the content of sodium and potassium in the albumen, yolk and whole egg was significantly $(P \leq 0.05)$ higher in eggs of chickens raised organically compared to the eggs of chickens reared in cages (Table 5-7).

Table 5. Content of $\mathrm{Na}$ and $\mathrm{K}$ in albumen depending on the rearing system

\begin{tabular}{lcc}
\hline \multirow{2}{*}{ Element in albumen } & \multicolumn{2}{c}{ Rearing system } \\
\cline { 2 - 3 } & $\begin{array}{c}\text { organic } \\
\end{array}$ & cage \\
\cline { 2 - 3 } & mean $\pm \mathrm{SD}$ & mean $\pm \mathrm{SD}$ \\
\hline $\mathrm{Na}, \mathrm{mg} / 100 \mathrm{~g}$ & $171.18^{\mathrm{a}} \pm 1.74$ & $150.37^{\mathrm{b}} \pm 2.65$ \\
$\mathrm{~K}, \mathrm{mg} / 100 \mathrm{~g}$ & $159.72^{\mathrm{a}} \pm 2.08$ & $138.91^{\mathrm{b}} \pm 2.02$ \\
\hline
\end{tabular}

Means in rows with superscripts $(a, b)$ differ significantly at $P \leq 0.05$.

Table 6. Content of $\mathrm{Na}$ and $\mathrm{K}$ in egg yolk depending on the rearing system

\begin{tabular}{lcc}
\hline \multirow{2}{*}{ Element in egg yolk } & \multicolumn{2}{c}{ Rearing system } \\
\cline { 2 - 3 } & $\begin{array}{c}\text { organic } \\
n=40\end{array}$ & $\begin{array}{c}\text { cage } \\
\end{array}$ \\
\cline { 2 - 3 } & mean \pm SD & mean \pm SD \\
\hline $\mathrm{Na}, \mathrm{mg} / 100 \mathrm{~g}$ & $58.03^{\mathrm{a}} \pm 1.02$ & $47.74^{\mathrm{b}} \pm 1.84$ \\
$\mathrm{~K}, \mathrm{mg} / 100 \mathrm{~g}$ & $109.92^{\mathrm{a}} \pm 1.84$ & $101.97^{\mathrm{b}} \pm 2.83$ \\
\hline
\end{tabular}

Means in rows with superscripts $(a, b)$ differ significantly at $P \leq 0.05$.

Table 7. Content of $\mathrm{Na}$ and $\mathrm{K}$ in the mixture of egg yolk and albumen depending on the rearing system

\begin{tabular}{lcc}
\hline & \multicolumn{2}{c}{ Rearing system } \\
\cline { 2 - 3 } $\begin{array}{c}\text { Element in the mixture of } \\
\text { egg yolk and albumen }\end{array}$ & $\begin{array}{c}\text { organic } \\
n=40\end{array}$ & $\begin{array}{c}\text { cage } \\
\mathrm{n}=40\end{array}$ \\
\cline { 2 - 3 } $\mathrm{Na}, \mathrm{mg} / 100 \mathrm{~g}$ & $147.40^{\mathrm{a}} \pm 5.01$ & $129.84^{\mathrm{b}} \pm 2.03$ \\
$\mathrm{~K}, \mathrm{mg} / 100 \mathrm{~g}$ & $139.82^{\mathrm{a}} \pm 1.42$ & $125.98^{\mathrm{b}} \pm 1.67$ \\
\hline
\end{tabular}

Means in rows with superscripts $(a, b)$ differ significantly at $P \leq 0.05$. 


\section{DISCUSSION}

Studies on egg quality in relation to housing systems has been carried out by Pištěková et al. (2006), Minelli et al. (2007), Golden et al. (2012), Lordelo et al. (2017), Kucukkoyuncu et al. (2017), and Gałązka-Czarnecka et al. (2019). However, the present study was conducted not to compare chicken housing systems, but only to compare the quality of the final product available to consumers. In this study, laying hens from the organic farm were found to lay slightly smaller eggs than laying hens from the cage system. The average weight of eggs from organic farming was $60.36 \mathrm{~g}$, while that of eggs from caged hens was $65.25 \mathrm{~g}$. Similar findings were reported by Minelli et al. (2007). This was also demonstrated in the present study. The eggs from both groups had a similar shape, with an egg shape index (ratio of long axis to short axis) of 1.27-1.28, which indicates the correct elongated shape. The eggs of smaller weight laid by hens from the organic system had a larger air cell than eggs from caged hens. Given the size of the air chamber, the eggs from both groups can be considered fresh, as the size of the air chamber ranged from 4.95 to $6.45 \mathrm{~mm}$, with a standard deviation of about 0.8 . The thickness of the egg shell was within the recommended range, which according to Świerczewska and Siennicka (2002) is 0.25 to $0.45 \mathrm{~mm}$ for chicken eggs. Previous studies do not indicate differences in the shell thickness of free range and cage eggs (Artan and Durmus, 2015; Yenice et al., 2016). Another important feature for consumers is the colour of the yolk. Kaźmierska et al. (2011) has shown that egg yolks from cage farming have a higher degree of colour on the La Roche scale. Similar observations have been made by Kucukkoyuncu et al. (2017), which may be due to synthetic pigment used in the diet of caged chickens. Our findings are in contrast with these reports, as the cage eggs had a lower degree of yolk colour than those obtained using organic methods, which is in agreement with the findings of Gałązka-Czarnecka et al. (2019). This may be explained by the green diet used on organic farms. The intensity of yolk colour is an important criterion for the consumer (Piątkowska et al., 2014). Polish consumers prefer eggs whose yolks have a yellow-orange colour (Śmiechowska and Podgórniak, 2013). There is a conviction among potential buyers that eggs with an intense yolk colour are more nutritious and are a valuable source of vitamins in the daily diet. For this reason consumers increasingly choose eggs with an orange yolk, corresponding to a value of 12 or more points on the La Roche scale (Kaźmierska et al., 2011). Another important feature for consumers and for processing is the size of the yolk, defined by its weight. Our research found that the yolks of eggs from organic farming weighed more, which is in conformity with Kucukkoyuncu et al. (2017).

In the present study, the albumen of eggs from caged hens had a significantly $(P \leq 0.05)$ higher total weight, and thus the weight of the thin and thick albumen was also greater than in organic eggs. The height of the thick albumen in the cage eggs was smaller, as was the number of Haugh units, which indicate the quality and freshness of eggs. The quality of the albumen was assessed based on Haugh units. Albumen quality is better when its height is greater and its spread is smaller after being broken out of the egg (Śmiechowska and Podgórniak, 2013). In a study by Calik et al. (2004), eggs obtained from a cage system had a slightly higher Haugh unit value than organic eggs. Similar observations have been reported by other authors (Gałązka-Czarnecka et al., 2019; Golden et al., 2012; Hidalgo et al., 2008; Yenice et al., 2016). Contrasting observations are found in the work of Castellini et al. (2006) and Lordelo et al. (2017), according to which Haugh units indicated that cage eggs were of poorer quality than organic eggs.

In our discussion of the micro-element content of eggs, reports by Kunachowicz et al. (2016) are used as a reference for the content of sodium and potassium in eggs. According to that study, the average sodium content in conventionally farmed eggs is $52 \mathrm{mg} / 100 \mathrm{~g}$, $200 \mathrm{mg} / 100 \mathrm{~g}$ and $141 \mathrm{mg} / 100 \mathrm{~g}$ in the yolk, albumen and whole egg (edible parts), respectively. In comparison with these results, in our research $\mathrm{Na}$ content was lower in the yolk of cage eggs, higher in the yolk of organic eggs, and lower in the albumen of eggs from both systems. Szablewski et al. (2013) analysed the content of selected elements in whole eggs (edible parts) from laying hens of four breeds subject to genetic resources conservation. They obtained the following results: Sussex $-160.1 \mathrm{mg} / 100 \mathrm{~g}$, Rhode Island Red - 179.4 mg/100 g, Green-legged Partridge - $167.4 \mathrm{mg} / 100 \mathrm{~g}$ and Yellow-legged 
Partridge $-182.0 \mathrm{mg} / 100 \mathrm{~g}$. In all four breeds the content of $\mathrm{Na}$ in the egg was higher than in the reference publication. Comparison of the Na content in the organic eggs tested in our study with the results reported by Szablewski et al. (2013) revealed significantly lower levels of this element (our study $-147.4 \mathrm{mg} / 100 \mathrm{~g}$ ). Similar research has been conducted by Bologa et al. (2013) on the eggs of Lohmann Brown crossbreds from conventional and organic farms. The authors showed a very large difference in the content of $\mathrm{Na}$ in the egg albumen depending on the housing system, by over $100 \mathrm{mg} / 100 \mathrm{~g}$. The content of this element was $95.77 \mathrm{mg} / 100 \mathrm{~g}$ in eggs from organic farming and up to $197.85 \mathrm{mg} / 100 \mathrm{~g}$ in eggs from conventional farming. The reverse relationship was shown in our study, i.e. higher $\mathrm{Na}$ content in the albumens of organic eggs $(171.18 \mathrm{mg} / 100 \mathrm{~g})$ as compared to caged eggs. In addition, in our research lower values for this element were obtained in both the egg yolk and the mixture in comparison with the research of Bologa et al. (2013), irrespective of the housing system. However, the relationships found were the same, i.e. Na content was higher in the yolk and mixture of organic eggs compared to cage eggs.

According to Kunachowicz et al. (2016), the potassium content in conventionally farmed eggs is 127 $\mathrm{mg} / 100 \mathrm{~g}, 154 \mathrm{mg} / 100 \mathrm{~g}$, and $133 \mathrm{mg} / 100 \mathrm{~g}$, in the yolk, albumen, and mixture of these components, respectively. In our research, the content of this element was lower in the yolk of both cage eggs and organic eggs. Potassium content in the albumen and the mixture was higher than the results reported by Kunachowicz et al. (2016) in the case of organic eggs, but lower in cage eggs. Szablewski et al. (2013) obtained the following potassium content in eggs: Sussex $-124.0 \mathrm{mg} / 100 \mathrm{~g}$, Rhode Island Red - 137.7 mg/100 g, Green-legged Partridge $-137.3 \mathrm{mg} / 100 \mathrm{~g}$ and Yellow-legged Partridge $-113.9 \mathrm{mg} / 100 \mathrm{~g}$. In the present study, we obtained a very similar potassium level in the organic eggs to that reported for the eggs of Green-legged Partridge laying hens. Bologa et al. (2013) obtained the following results for potassium content: conventional farming $-512.03 \mathrm{mg} / 100 \mathrm{~g}, 10.38 \mathrm{mg} / 100 \mathrm{~g}$, and $173.58 \mathrm{mg} / 100 \mathrm{~g}$ in the yolk, albumen, and mixture, respectively; organic farming $-480.96 \mathrm{mg} / 100 \mathrm{~g}$, $11.12 \mathrm{mg} / 100 \mathrm{~g}$, and $158.17 \mathrm{mg} / 100 \mathrm{~g}$ in the yolk, albumen, and mixture, respectively. Our study found lower P content in the yolk and mixture of cage eggs and higher content in the albumen. The same pattern was shown for the organic eggs; only in the mixture was the potassium content about $20 \mathrm{mg} / 100 \mathrm{~g}$ higher.

\section{CONCLUSION}

The research results indicate a slightly better quality of eggs from organic farming compared to eggs from cages in terms of most physical properties as well as the content of macro-elements. The eggs in both systems are produced following scientific management practices. There are many myths among consumers regarding the nutritional quality of eggs produced in different systems. The information presented here can be useful for raising awareness among consumers selecting eggs. Nevertheless, irrespective of the chicken housing system, eggs are a highly valuable product and a source of many bioactive substances and elements, which can correct deficiencies in the human diet.

\section{REFERENCES}

Abd El-Hack, M. E., Chaudhry, M. T., Mahrose, Kh. M., Noreldin, A., Emam, M., Alagawany, M. (2018). The efficacy of using exogenous enzymes cocktail on production, egg quality, egg nutrients and blood metabolites of laying hens fed distiller's dried grains with solubles. J. Anim. Physiol. Anim. Nutr., 102(2), e726-e735. http:// dx.doi.org/10.1111/jpn.12825

Anders, E. (2004a). Zasady sortowania i znakowania jaj kurzych w nowych przepisach Unii Europejskiej - cz. 1 [Rules for sorting and labelling chicken eggs in the new EU regulations - part 1]. Pol. Drob., 3, 49-50 [in Polish].

Anders, E. (2004b). Zasady sortowania i znakowania jaj kurzych w nowych przepisach Unii Europejskiej - cz. 2 [Rules for sorting and labelling chicken eggs in the new EU regulations - part 2]. Pol. Drob., 4, 17-19 [in Polish].

Artan, S., Durmus, I. (2015). Köy, serbest ve kafes sistemlerinde üretilen yumurtaların kalite özellikleri bakımından karşılaştırılması. Akad. Ziraat Dergisi, 4, 89-97.

Babicz-Zielińska, E. (2001). Zachowanie konsumenta w stosunku do żywności i żywienia [Consumer behavior in relation to food and nutrition]. Żywn. Nauka Technol. Jakość, 4(29), 5-13 [in Polish].

Bełkot, Z., Gondek, M. (2014). Zanieczyszczenie bakteryjne powierzchni jaj spożywczych w zależności od systemu 
Banaszewska, D., Biesiada-Drzazga, B., Marciniuk, M., Hrnčár, C., Arpášová, H., Kaim-Mirowski, S. (2020). Comparison of the quality of cage and organic eggs available in retail and their content of selected macro-elements. Acta Sci. Pol. Technol. Aliment., 19(2), 159-167. http://dx.doi.org/10.17306/J.AFS.2020.0797

utrzymania kur niosek [Bacterial pollution of consumer egg surfaces with regards to the maintenance system of laying hens]. Med. Weter., 70(6), 378-382 [in Polish].

Biesiada-Drzazga, B., Banaszewska, D., Wielogórska, K., Kaim-Mirowski, S. (2020). The effect of the genetic origin of hens on selected egg traits. Acta Sci. Pol. Technol. Aliment., 19(1), 101-107. http://dx.doi.org/10.17306/J. AFS.2020.0757

Bologa, M., Pop, I. M., Albu, A. (2013). Research on chemical composition of chicken egg from different systems of production. Lucrări Științifice Univ. Științe Agric. Med. Vet., Ser. Zootehnie, 59, 80-85.

Calik, J., Połtowicz, K., Krawczyk, J., Wężyk, S. (2004). Zmiany cech jakości jaj z chowu klatkowego i ściółkowego podczas ich przechowywania w różnych warunkach [Changes in quality traits of eggs from battery-cage eggs and litter systems during storage under various conditions]. Mat. 69. Zjazdu PTZ (pp. 87-88). Siedlce 21-23.09.2004 [in Polish].

Castellini, C., Perella, F., Mugnai, C. Dal Bosco, A. (2006). Welfare, productivity and qualitative traits of egg in laying hens reared under different rearing systems. Poster at: XII European Poultry Conference, Verona, 10-14 September.

Dyrektywa Komisji 2002/4/WE z dnia 30 stycznia 2002 r. w sprawie rejestracji zakładów hodujących kury nioski, objętych dyrektywą Rady 1999/74/WE (2002). Dz.U. UE L 030, 31.1.2002.

Gałązka-Czarnecka, I., Korzeniewska, E., Czarnecki, A., Sójka, M., Kiełbasa, P., Dróżdź, T. (2019). Evaluation of quality of eggs from hens kept in caged and free-range systems using traditional methods and ultra-weak luminescence. Appl. Sci., 9, 2430. http://dx.doi.org/10.3390/ app9122430

Golden, J. B., Arbona, D. V., Anderson, K. E. (2012). A comparative examination of rearing parameters and layer production performance for brown egg-type pullets grown for either free-range or cage production. J. Appl. Poult. Res., 21, 95-102. http://dx.doi.org/10.3382/ japr.2011-00370

Hidalgo, A., Rossi, M., Clerici, F., Ratti, S. (2008). A market study on the quality characteristics of eggs from different housing systems. Food Chem., 106, 1031-1038. https://doi.org/10.1016/j.foodchem.2007.07.019

Hu, F. B., Manson, J. E., Willet, W. C. (2001). Types of dietary fat and risk of coronary heart disease: a critical review. J. Am. Coll. Nutr., 20, 5-19. http://dx.doi.org/10.1 080/07315724.2001.10719008

Kajdan-Zasnarska, I. (2013). Warunki utrzymywania drobiu w świetle obowiązujących przepisów [Conditions for keeping poultry in the light of applicable regulation]. Poznań: Centrum Doradztwa Rolniczego w Brwinowie, Oddział w Poznaniu.

Kaźmierska, M., Kosmalski, B., Jarosz, B., Ligor, M., Trziszka, T. (2011). Wpływ zróżnicowanego systemu chowu kur na zawartość luteiny w jajach [Effect of a different chicken farming systems on lutein content in eggs]. Żywn. Nauka Technol. Jakość, 5 (78), 75-84 [in Polish].

Kijowski, J., Leśnierowski, G., Cegielska-Radziejewska, R. (2013). Jaja cennym źródłem składników bioaktywnych [Eggs as a valuable source of bioactive substances]. Żywn. Nauka Technol. Jakość, 5(90), 29-41 [in Polish]. Krawczyk, J., Gornowicz, E. (2010). Quality of eggs from hens kept in two different free-range systems in comparison with barn system. Arch. Geflügelkd., 74(3), 151-157.

Krawczyk, J., Sokołowicz, Z., Szymczyk, B. (2011). Effect of housing system on cholesterol, vitamin and fatty acid content of yolk and physical characteristics of eggs from Polish native hens. Arch. Geflügelkd., 75(3), 151-157.

Kucukkoyuncu, E., Agma Okur, A., Tahtabicen, E., Korkmaz, F., Samli, H. E. (2017). Comparing quality of free range and battery cage eggs. Eur. Poult. Sci., 81. http://dx.doi.org/10.1399/eps.2017.197

Kunachowicz, H., Nadolna, I., Iwanow, K., Przygoda, B. (2016). Wartość odżywcza wybranych produktów spożywczych i typowych potraw [The nutritional value of selected food products and typical dishes]. Warszawa: Wyd. Lek. PZWL [in Polish].

Lordelo, M., Fernandes, E., Bessa, R. J. B., Alves, S. P. (2017). Quality of eggs from different laying hen production systems, from indigenous breeds and specialty eggs. Poult. Sci., 6 (5), 1485-1491. http://dx.doi. org/10.3382/ps/pew409

McNamara, D. J. (2010). Eggs. A world of possibilities. Poult. World, 26(7), 36-37.

Minelli, G., Sirri, F., Folegatti, E., Meluzzi, A., Franchini, A. (2007). Egg quality traits of laying hens reared in organic and conventional systems. Ital. J. Anim. Sci., 6, 728-730. http://dx.doi.org/10.4081/ijas.2007.1s.728

Nain, S., Renema, R. A., Korver, D. R., Zuidhof, M. J. (2012). Characterization of the $n-3$ polyunsaturated fatty acid enrichment in laying hens fed an extruded flax enrichment source. Poult. Sci., 91, 720-1732. http:// dx.doi.org/10.3382/ps.2011-02048

Nys, Y., Bain, M., Van Immerseelet, F. (2011). Improving the safety and quality of eggs and eggs products. Woodhead Publ., UK. 
Banaszewska, D., Biesiada-Drzazga, B., Marciniuk, M., Hrnčár, C., Arpášová, H., Kaim-Mirowski, S. (2020). Comparison of the quality of cage and organic eggs available in retail and their content of selected macro-elements. Acta Sci. Pol. Technol. Aliment., 19(2), 159-167. http://dx.doi.org/10.17306/J.AFS.2020.0797

Piątkowska, M., Jedziniak, P., Zmudzki, J. (2014). Barwniki stosowane $\mathrm{w}$ produkcji jaj - aspekty kliniczne [Dyes used in egg production - clinical aspects]. Mag. Weter., 23, 351-358 [in Polish].

Pištěková, V., Hovorka, M., Večerek, V., Straková, E., Suchý, P. (2006). The quality comparison of eggs laid by laying hens kept in battery cages and in a deep litter system. Czech J. Anim. Sci., 51(7), 318-325. https://doi. org/10.17221/3945-CJAS

Rozporządzenie Komisji (WE) nr 589/2008 z dnia 23 czerwca 2008 r., ustanawiające szczegółowe zasady wykonywania rozporządzenia Rady (WE) nr 1234/2007 $\mathrm{w}$ sprawie norm handlowych $\mathrm{w}$ odniesieniu do jaj (2008). Dz.U. UE L 163/6, 24.6.2008 [in Polish].

Seuss-Baum, I. (2007). Nutritional evaluation of egg compounds. In R. Huopalahti, M. Lopez-Fandiño, A. R. Schade (Eds.), Bioactive egg compounds (pp. 117-144). Berlin - Heildelberg, Germany: Springer.

Sim, J. (2006). Why designer eggs? A Canadian story for egg lovers around the world. In J. S. Sim, H. H. Sunwoo (Eds.), The amazing egg (pp. 1-13). Edmonton, Canada: University of Alberta.

Surai, P. F., Sparks, N. H. C. (2001). Designer eggs: From improvement of egg composition to functional food. Trends Food Sci., Technol., 12, 7-16.

Szablewski, T., Gornowicz, E., Stuper-Szablewska, K., Kaczmarek, A., Cegielska-Radziejewska, R. (2013). Skład mineralny treści jaj kur ras zachowawczych $\mathrm{z}$ chowu ekologicznego [Mineral composition of the contents of eggs of organically reared hens of conserved breeds]. Żywn. Nauka Technol. Jakość, 5(90), 42-51.

Szymanek, E., Andraszek, K., Banaszewska, D., Drabik, K., Batkowska, J. (2019). Content of selected inorganic compounds in the eggs of hens kept in two different systems: organic and battery cage. Arch. Anim. Breed., 62, 431-436. http://dx.doi.org/10.5194/aab-62-431-2019

Śmiechowska, M., Podgórniak, P. (2013). Badanie i ocena wybranych parametrów jakościowych ekologicznych jaj kurzych dostępnych na rynku trójmiasta [Study and assessment of selected quality parameters of organic hen eggs available on the tri-city market]. J. Res. Appl. Agric. Eng., 58(4), 186-189 [in Polish].

Świerczewska, E., Siennicka, A. (2012). Jaja konsumpcyjne - budowa i jakość [Table eggs - structure and quality]. Pol. Drob., 1, 19-22.

Trziszka, T. (2009). Nowej generacji nutraceutyki na bazie surowca jajczarskiego [A new generation of nutraceuticals based on raw egg]. Mat. Konf. PTTŻ „Żywność wzbogacona i nutraceutyki” (pp. 18-19). Oddz. Małopolski PTTŻ, Kraków [in Polish].

Trziszka, T., Różański, H., Polanowski, A. (2013). Eggs as a very promising source of biomedical and nutraceutical preparations: a review. J. Life Sci., 7, 862-877. http:// dx.doi.org/10.17265/1934-7391/2013.08.012

Walczak, J., Bocian, S., Trziszka, T., Buszewski, B. (2016). Hyphenated analytical methods in determination of biologically active compounds in hen's eggs. Crit. Rev. Anal. Chem., 46, 201-212. https://doi.org/10.1080/1040 8347.2015.1023428

Wellman-Labadie, O., Picman, J., Hincke, M. T. (2007). Avian antimicrobial proteins: structure, distribution and activity. Worlds Poult. Sci. J., 63, 421-437. http:// dx.doi.org/10.1017/S0043933907001559

Wężyk, S., Gilewski, R. (2018). Spożycie jaj a zdrowie konsumentów [Egg consumption and consumer health]. Pol. Drob., 10, 36-38 [in Polish].

Wielewska, I. (2004). Wymagania jakościowe konsumentów żywności w świetle badań [Quality requirements of food consumers in the light of research]. Rocz. Nauk. SERiA, 6, 2, 330-334 [in Polish].

Williams, K. C. (1992). Some factors affecting albumen quality with particular reference to Haugh unit score. Worlds Poult. Sci., J., 48(1), 5-16.

Yenice, G., Kaynar, O., Ileriturk, M., Hira, F., Hayirli, A. (2016). Quality of eggs in different production systems. Czech J. Food Sci., 34, 370-376. http://dx.doi. org/10.17221/33/2016-CJFS 